\title{
Fostering achievement and retention in basic science using simulation and demonstration strategies
}

\author{
Joyce H. Musa1 ${ }^{1}$, Emmanuel E. Achor ${ }^{1}$, Barnabas O. Ellah2,* \\ 1Benue State University, Nigeria \\ ${ }^{2}$ Joseph Sauwan Tarka University, Nigeria
}

\begin{abstract}
The study investigated the better strategy to use in fostering achievement and retention in Basic Science considering simulation and demonstration strategies. The study also compared the achievement as well as the retention of female and male students in basic science when exposed to simulation strategy. The research region is Kogi State's Ankpa Education Zone. A multistage sampling strategy was used to choose 120 Basic II students from four schools in the research region. The study used a quasi-experimental design. Data were analyzed using means and standard deviations, while ANCOVA was utilized to test the hypotheses. The study's results indicated that students taught using the simulation technique achieved considerably better mean achievement and retention scores in Basic Science than students taught using the demonstration strategy. Additionally, no significant difference in mean achievement scores between male and female students taught utilizing the simulation teaching technique was discovered. The research demonstrates a substantial difference in the mean retention scores of male and female students in Basic Science who are taught utilizing a simulation technique. Following the findings, it was suggested that Science teachers should use simulation strategy for the teaching of various topics in Basic Science to improve students' achievement in Basic Science.
\end{abstract}

Keywords: Simulation strategy, demonstration strategy, achievement, retention, gender

\section{Membina prestasi dan retensi dalam sains dasar menggunakan strategi simulasi dan demonstrasi}

\begin{abstract}
Abstrak: Studi ini menyelidiki strategi yang lebih baik untuk digunakan dalam mendorong prestasi dan retensi dalam Ilmu Dasar dengan mempertimbangkan strategi simulasi dan demonstrasi. Studi ini juga membandingkan pencapaian serta retensi siswa perempuan dan laki-laki dalam sains dasar ketika dihadapkan pada strategi simulasi. Wilayah penelitian adalah Zona Pendidikan Ankpa Negara Bagian Kogi. Strategi multistage sampling digunakan untuk memilih 120 siswa Basic II dari empat sekolah di wilayah penelitian. Penelitian ini menggunakan desain eksperimen semu. Data dianalisis menggunakan mean dan standar deviasi, sedangkan ANCOVA digunakan untuk menguji hipotesis. Hasil penelitian menunjukkan bahwa siswa yang diajar menggunakan teknik simulasi mencapai prestasi ratarata dan skor retensi yang jauh lebih baik dalam Ilmu Dasar daripada siswa yang diajar menggunakan strategi demonstrasi. Selain itu, tidak ditemukan perbedaan yang signifikan dalam skor pencapaian rata-rata antara siswa laki-laki dan perempuan yang diajar menggunakan teknik pengajaran simulasi. Penelitian ini menunjukkan perbedaan substansial dalam skor retensi rata-rata siswa laki-laki dan perempuan dalam Ilmu Dasar yang diajarkan menggunakan teknik simulasi. Menyusul temuan tersebut, disarankan agar guru IPA menggunakan strategi simulasi untuk pengajaran berbagai topik IPA untuk meningkatkan prestasi belajar IPA siswa.
\end{abstract}

Kata Kunci: Strategi simulasi, strategi demonstrasi, prestasi, retensi, gender

Received: $27-08-2021$

Accepted: 27-09-2021
To cite this article: Musa, J. H., Achor, E. E., \& Ellah, B. O. (2021). Fostering achievement and retention in basic science using simulation and demonstration strategies. Journal of Research in Instructional, 1(2), 95-108. https://doi.org/10.30862/jri.v1i2.19 


\section{INTRODUCTION}

Basic Science as a subject in Nigeria, Introduces pupils and students under basic education program in primary school to the basic rudiments of science. The National Policy in Education defined the subject as that aspect whose study leads to acquiring practical skills and basic scientific knowledge. The main reason for teaching basic science is to widen students' knowledge, which enables them to appreciate the unity among science subjects (Nwafor, 2015).

Basic science is content that secondary school students will find before they study science at the next level. Secondary students should be prepared to study this content so that they can easily understand score science content such as physics, biology and chemistry at the next level (Oludipe, 2012). Basic science is a subject that is available to all Upper Basic Level students. This implies that in order to learn sciences at the senior secondary school level successfully, students must have a solid foundation in basic science at the Upper Basic level. Teachers, school administrators, curriculum experts, and society at large believe that basic science prepares and grooms the students to do well in science subjects in their senior classes and in university education. The basic science curriculum was reviewed in 2007 by Nigeria Education Research and Development Council (NERDC). Some new topics like habitat, desertification, drug abuse, and their effects were added, among others, to the existing one. Basic Science is the bedrock for subsequent specialist science study, and it is of great significance in building individuals.

Ellah and Achor (2017) opined that basic science is one of the science subjects designed to expose learners to scientific and technological knowledge and skills that will assist them in making informed decisions, developing strategies, and learning to contribute meaningfully in the contemporary society. Ayodele (2016) explained that basic science is the bedrock of future understanding of advanced studies in science, engineering, and technology. Basic science assists the learner in laying a solid foundation for subsequent studies in science, teaching, and Engineering.

The Basic Education Certificate Examination (BECE) results for ten years (20102019) for Ankpa Education Zone shows that performance at distinction and credit pass recorded $0.3 \%$ and $1.1 \%$ respectively, for only 2014 while other years it is as low as $0.6 \%$. This is evidenced in the low achievement of students in the Ankpa Education Zone, and the total credit pass at distinction level in percentage is $0.0 \%$ for ten years. Also, the credit pass is between $0.0 \%$ and $0.1 \%$, while the merit is between $2.7 \%$ and $5.5 \%$. Overall pass is between $2.7 \%$ and $5.6 \%$ in the BECE examination. This continuous poor achievement in science, skills, and knowledge levels among students suggests that the existing educational input isn't strong or isn't good. Ajayi (2019), Bhure et al. (2021), and Ruto et al. (2021) reported that the poor academic achievement of students in science-related subjects results from poor and ineffective instructional strategies used by some teachers, and constant use of the conventional methods are some of the factors contributing to this poor academic achievement. Researchers such as Obiekwe (2008) and Oludipe (2012) have indicated that scientific instruction in Nigerian secondary schools falls short of the required standard, and several of the teaching tactics employed have been labeled as inappropriate and inadequate by these researchers (Igboegwu, 2012).

Unfortunately, these students may not be able to apply what they have learned to reallife conditions because it is learned without adequate interactions using inappropriate and 
weak teaching strategies. The interactive and collaborative setting that this generation of students need due to their exposure to the internet, computer use, mobile, hand-on-mind, and other technological devices are issues that may be best managed via the employment of simulation strategy.

Simulation strategy is a strategy of instruction that focuses on imitation of the procedure of the actual-world process or system to aid learning and create interest in any subject. It is observed that students exposed to mathematics and social studies simulation strategy achieved higher than their counterparts instructed with chalk and talk strategy of teaching (Adeyemi \& Ajibade, 2011; Seay \& Jouhingen, 2013). This brings to the fore that simulation strategy could bring better results in terms of students' achievement than conventional strategy. Despite the fact that today's students can communicate with individuals all over the world and virtual classrooms are becoming more widespread, many instructors still use outdated methods of teaching Basic Science (Sidi, 2009). Achor and Eriba (2010) argued that successful communication in the teaching-learning process requires a teacher-student contact including verbal, gestural, and resource instrumentality. According to the authors, a teaching-learning method must provide a chance for parties to participate actively in the process.

Simulations are used to forecast the result of a real-world event and may be used to evaluate and appraise any described and unrestricted system capable of describing and solving complicated issues. Additionally, simulation accelerates teachers' educational potential and student learning, allowing students to learn through simulation strategy (Hursen, 2015); the author discovered that students taught through simulation strategy were more successful than students taught through the traditional approach in Physics. According to Cayirci (2013), the fundamental problem for our educational system is to harness basic science learning to provide interesting, relevant, and individualized learning experiences for all students that reflect their everyday lives and future realities. According to Sokolowski and Banks (2009), simulation is a staged reproduction of an event or idea by manipulating the classroom environment in order to increase students' knowledge of the concept or event's nature. With a wealth of information practically at their fingertips, students may achieve educational and learning objectives quicker and more effectively than ever before. Simulation strategy is a process of instruction that focuses on imitation of the operation of the real-world process or system to aid learning and create interest in any subject. It was observed that Mathematics, Social studies students exposed to simulation strategy achieved higher than their counterparts taught with chalk and talk method of teaching (Adeyemi \& Ajibade, 2011; Seay \& Jouhingen, 2013). This brings to the fore that simulation could bring better results in terms of students' achievement than demonstration strategy.

On the other hand, demonstration approach refers to a style of teaching in which the instructor is the primary actor and the learners observe with the goal to act afterwards, and it entails demonstrating how something works or the steps involved. Additionally, it provides a realistic setting for the course of study by requiring students to develop skills in real-world settings while using equipment and materials; it also serves to encourage students when conducted by qualified instructors. It is beneficial in demonstrating proper procedures. The instructor demonstrates and explains how to perform whatever the learners are required to do at the conclusion of the class (Ameh, Daniel \& Akus, 2007). 
Utilizing a demonstrative teaching method in which the instructor controls all class activities from the beginning to the end stifles students' initiative and also stops them from thoroughly investigating and comprehending complicated concepts. Wood and Gentile (2003), Blair et al. (2007) statements of disdain for the conventional teaching strategy as represented by the demonstration strategy of teaching Basic Science gives less opportunity for effective retention and achievement in Basic Science class.

Students are good at retention are good at remembering things they have done in the past and being able to use them when they need to (Bunkola \& Idowu, 2012). Because a learner who does not make many mistakes when they repeat what they have learned shows that they have learned it. This means that if it fades away, you won't learn as much and your performance would be poor (Asogwa et al., 2016).

Examining how well girls and boys do in terms of gender is often based on how different they are in terms of socio-cultural differences. As a result of a sex role stereotype, some jobs are thought to be for men (engineering arts and crafts, farming, etc.) and other jobs are thought to be for women (catering, typing, nursing, etc.). In this way, boys get the most difficult and complex tasks, while girls are supposed to do the easier and less demanding tasks. Some research has revealed that there are no significant differences in male-female math performance at any level, but most have found that there are gender differences (Oludipe, 2012, Ellah \& Achor, 2015). Babajide (2010) also said that science subjects like physics and chemistry are given a more masculine look by teachers. It doesn't matter that boys and girls are different, that Basic Science is a foundation for all the other science subjects in secondary school, or that science educators have tried to make teaching and learning more effective. Students still don't remember or do well on tests (Agogo \& Naakaa, 2014). The reason for this failure has been attributed to poor strategies of teaching and hard learning (Pember \& Achor, 2017). The Problem of this study is "which is a better strategy to use in boosting achievement and retention of learner in Basic Science, considering simulation strategy and demonstration strategy?

To be more specific, the research intended to:

1. Determine whether or not there is a difference in the accomplishment of Upper basic II students who are taught using the simulation demonstration strategies.

2. Determine if there is a difference in retention between Upper basic II students who are taught using simulation and demonstration strategies.

3. Examine the differences in performance between female and male students in basic science when they are subjected to simulation strategy.

4. Four, when students in fundamental science are exposed to a simulation strategy, compare the scores retention of female and male students.

\section{METHOD}

The research design adopted for this study was a quasi-experimental design. The sample for the study comprises 120 from 1450 Upper Basic II students in 36 secondary schools of Ankpa Local government Area. Purposive sampling was used to select four schools. The reason for using the purposive sampling technique is to enable the researchers to select only schools that certify the necessary requirements of the study. Two schools each are allocated to experimental and control groups by a flip of the coin. Only co-educational schools were used since gender is a moderating variable. The instrument for data collection 
is Basic Science Performance Test (BSPT). The researchers developed the Basic Science Performance Test (BSPT). This contains 35 items test questions drawn on the concept of Basic Science in the Upper Basic II Curriculum. Each question has four options A, B, C, and $\mathrm{D}$, and students are expected to circle the options they consider to be correct. Each question carries one mark. The instruments were used for pre and post-tests as well as retention tests. The content and face validation of BSPT were carried out by three experts from the Department of Science and Mathematics Education, Benue State University, Makurdi, and one experienced senior secondary school Basic Science teacher in Ankpa Education Zone. The psychometric analysis of the BSPT was done to determine the quality of the test item in terms of how difficult the test item may be and its discrimination and distracting powers. The reliability coefficient of BSPT was established using Kunder-Richardson 20 Formula (K$\mathrm{R}-20$ ) and found to be 0.98 . The BSPT was administered to the students in the first week as a pre-test; the BSPT was administered to the students in the fifth week as a post-test. A reshuffled BSPT test was administered BSPT was administered to the students in the seventh week as a retention test. The scores for the experimental and the control group were recorded accordingly. The test items in the pre-test, post-test, and retention test were scored one mark each. The data collected were analyzed using Mean and Standard Deviation to answer all the research questions, while Analysis of Covariance (ANCOVA) was used to test the hypotheses formulated for the study at a 0.05 level of significance. ANCOVA took care of any error as a result of initial differences among the research subjects (Emaikwu, 2019).

\section{RESULTS}

Table 1. Mean, mean gain, and standar deviation of pre and post-test

\begin{tabular}{llccc}
\hline Strategy & & PreTest & PostTest & Mean gain \\
\hline \multirow{3}{*}{ Simulation Strategy } & Mean & 9.61 & 30.05 & 20.44 \\
\cline { 2 - 5 } & $\mathrm{N}$ & 56 & 56 & \\
\cline { 2 - 5 } & Std. Deviation & 2.23 & 1.88 & \\
\hline \multirow{3}{*}{ Demonstration Strategy } & Mean & 11.66 & 18.17 & 6.51 \\
\cline { 2 - 5 } & $\mathrm{N}$ & 64 & 64 & \\
\cline { 2 - 5 } & Std. Deviation & 1.61 & 3.64 & 13.93
\end{tabular}

There was a big difference in how well Upper Basic II students who learned basic science through simulation and demonstration did. The table 1 shows that 56 students were taught through simulation, and 64 students were taught through demonstration. Pre-test: 9.61 with a standard deviation of 2.23; post-test: 30.54 with a standard deviation of $1.88 \mathrm{In}$ the pre-test, students who were taught Basic Science through demonstration scored 11.66 out of 100. In the post-test, they scored 18.17 out of 100 . Table 1 also shows that students who were taught Basic Science through simulations gained 20.44 points, while students who were taught Basic Science through demonstrations gained 6.51 points. This means that students who learned Basic Science through simulations had a mean achievement score of 13.93 points more than students who learned it through demonstrations. 
Table 2. Mean, and standard deviation of retention scores of upper basic II students in basic science taught using simulation strategy and demonstration strategy

\begin{tabular}{llccc}
\hline Strategy & & PreTest & PostTest & Mean gain \\
\hline \multirow{3}{*}{ Simulation Strategy } & Mean & 9.61 & 27.25 & 17.64 \\
\cline { 2 - 5 } & $\mathrm{N}$ & 56 & 56 & \\
\cline { 2 - 5 } & Std. Deviation & 2.23 & 2.37 & \\
\hline \multirow{3}{*}{ Demonstration Strategy } & Mean & 11.66 & 12.34 & 0.68 \\
\cline { 2 - 5 } & $\mathrm{N}$ & 64 & 64 & \\
\cline { 2 - 5 } & Std. Deviation & 1.61 & 4.76 & 16.96 \\
\hline Mean difference & & & &
\end{tabular}

It shows how much better Upper Basic II students who learned Basic Science through simulation and demonstration did than those who learned through demonstration. The table 1 shows that 56 students were taught through simulation, and 64 students were taught through demonstration. The table also shows that students who were taught Basic Science through simulations had a mean retention score of 9.61, with a standard deviation of 2.23 in the pre-test, and a mean retention score of 27.25 with a standard deviation of 2.37 after the test. The mean retention score for students who were taught Basic Science through demonstration is 11.66, with a standard deviation of 1.61 in the pre-test and 12.34 in the post-test, with a standard deviation of 4.76 in each. Table 2 also shows that students who were taught Basic Science through simulations gained 17.64 points, while students who were taught Basic Science through demonstrations gained 0.68 points. It is 16.96 points in the favor of Upper Basic II students who are taught Basic Science with a simulation strategy compared to students who are taught with an example, which means that they are more likely to remember what they learned.

Table 3. Mean and standard deviation of male and female students' achievement

\begin{tabular}{llccc}
\hline Gender & & PreTest & PostTest & Mean gain \\
\hline \multirow{3}{*}{ Male } & Mean & 9.46 & 30.29 & 20.83 \\
\cline { 2 - 5 } & $\mathrm{N}$ & 28 & 28 & \\
\cline { 2 - 5 } & Std. Deviation & 2.13 & 1.98 & \\
\hline \multirow{3}{*}{ Female } & Mean & 9.75 & 29.82 & 20.07 \\
\cline { 2 - 5 } & $\mathrm{N}$ & 28 & 28 & \\
\cline { 2 - 5 } Mean difference & Std. Deviation & 2.35 & 1.79 & 0.76 \\
\hline
\end{tabular}

Table 3 shows the difference in how well male and female students did in Basic Science when they used simulation. The table shows that 28 male students and 28 female students learned about Basic Science through the simulation teaching method. The table shows that the mean achievement scores of male students who were exposed to Basic Science through simulation were 9.46 in the pre-test and 30.29 in the post-test. The standard deviation was 2.13. Female students who were exposed to Basic Science using simulation strategy had a mean achievement score of 9.75 from the pre-test and 29.82 from the post-test. Table 3 also shows that male students who were exposed to Basic Science 
using simulation strategy had a mean gain of 20.83 and female students who were exposed to Basic Science using simulation strategy had a mean gain of 20.07. The difference in how well male and female students do in Basic Science when they use a simulation teaching method is 0.76 .

Table 4. Mean and standard deviation of male and female students' mean retention scores in basic science when exposed to simulation strategy

\begin{tabular}{llccc}
\hline Gender & & PreTest & PostTest & Mean gain \\
\hline \multirow{3}{*}{ Male } & Mean & 9.46 & 28.61 & 19.15 \\
\cline { 2 - 5 } & $\mathrm{N}$ & 28 & 28 & \\
\cline { 2 - 5 } & Std. Deviation & 2.13 & 2.19 & \\
\hline \multirow{3}{*}{ Female } & Mean & 9.75 & 25.89 & 16.14 \\
\cline { 2 - 5 } & $\mathrm{N}$ & 28 & 28 & \\
\cline { 2 - 5 } & Std. Deviation & 2.35 & 1.66 & 3.01 \\
\hline Mean difference & & & &
\end{tabular}

Female and male students who used a simulation strategy to learn Basic Science had different mean retention scores than those who didn't. The table shows that 28 male students and 28 female students learned about Basic Science through simulation. The table shows that the mean retention scores for male students who were taught Basic Science through simulation were 9.46 in the pre-test and 28.61 in the post-test. This means that the students who were exposed to simulation teaching had a standard deviation of 2.13 in both tests. Female students who were exposed to Basic Science using simulation strategy had mean retention scores of 9.75 in pre-test and 25.89 in post-test. Table 4 also shows that male students who were exposed to Basic Science using simulation strategy had mean gains of 19.15 and female students who were exposed to Basic Science using simulation strategy had mean gains of 16.14. Male students who use a simulation strategy in Basic Science have 3.01 more points than female students who don't use a simulation strategy in Basic Science.

Table 5. ANCOVA result

\begin{tabular}{lcccccc}
\hline \multicolumn{1}{c}{ Source } & $\begin{array}{c}\text { Type III Sum } \\
\text { of Squares }\end{array}$ & df & $\begin{array}{c}\text { Mean } \\
\text { Square }\end{array}$ & F & Sig. & $\begin{array}{c}\text { Partial Eta } \\
\text { Squared }\end{array}$ \\
\hline Corrected Model & $4237.11^{\mathrm{a}}$ & 2 & 2118.56 & 245.60 & 0.00 & 0.81 \\
\hline Intercept & 1774.35 & 1 & 1774.35 & 205.70 & 0.00 & 0.64 \\
\hline PreTest & 20.69 & 1 & 20.69 & 2.40 & 0.12 & 0.02 \\
\hline Strategies & 3524.93 & 1 & 3524.93 & 408.63 & 0.00 & 0.78 \\
\hline Error & 1009.26 & 117 & 8.63 & & & \\
\hline Total & 72744.00 & 120 & & & & \\
\hline Corrected Total & 5246.37 & 119 & & & & \\
\hline
\end{tabular}

Table 5 reveals that $F(1,117)=408.63 ; p=0.00<0.05$. Since $p$ is less than 0.05 , the null hypothesis is rejected. This follows that there is a significant difference between the achievement of students in Basic Science who are exposed to simulation strategy and those taught using demonstration strategy. Thus, there is a significant difference between the 
mean achievement scores of students in Basic science who are applied to simulation strategy and those taught using demonstration strategy. The partial Eta square of 0.78 was obtained for the strategy meaning that $78 \%$ of the Basic Science students' achievement can be accounted for by the strategies employed in the teaching.

Table 6. ANCOVA of mean retention scores of students in upper basic II basic science applied to simulation strategy and demonstration strategy

\begin{tabular}{lcccccc}
\hline \multicolumn{1}{c}{ Source } & $\begin{array}{c}\text { Type III Sum } \\
\text { of Squares }\end{array}$ & df & $\begin{array}{c}\text { Mean } \\
\text { Square }\end{array}$ & F & Sig. & $\begin{array}{c}\text { Partial Eta } \\
\text { Squared }\end{array}$ \\
\hline Corrected Model & $6662.02^{\mathrm{a}}$ & 2 & 3331.01 & 228.29 & 0.00 & 0.80 \\
\hline Intercept & 1870.92 & 1 & 1870.92 & 128.22 & 0.00 & 0.52 \\
\hline PreTest & 25.75 & 1 & 25.75 & 1.77 & 0.19 & 0.02 \\
\hline Strategy & 4814.67 & 1 & 4814.67 & 329.97 & 0.00 & 0.74 \\
\hline Error & 1707.19 & 117 & 14.59 & & & \\
\hline Total & 53068.00 & 120 & & & & \\
\hline Corrected Total & 8369.20 & 119 & & & & \\
\hline
\end{tabular}

$F(1,117)=329.97 ; p=0.000 .05$, as seen in Table 6 . As a result, the null hypothesis is rejected. This suggests that the retention rates of students in upper basic II Basic science who were taught using simulations vs those who were taught using demonstrations are significantly different. The technique earned a partial Eta square of 0.74, indicating that 74 percent of Basic Science students' recall may be attributable to the tactics used to teach basic science.

Table 7. ANCOVA result of achievement of female and male students in basic science applied to simulation strategy

\begin{tabular}{lcccccc}
\hline \multicolumn{1}{c}{ Source } & $\begin{array}{c}\text { Type III Sum } \\
\text { of Squares }\end{array}$ & df & $\begin{array}{c}\text { Mean } \\
\text { Square }\end{array}$ & F & Sig. & $\begin{array}{c}\text { Partial Eta } \\
\text { Squared }\end{array}$ \\
\hline Corrected Model & $16.26^{\mathrm{a}}$ & 2 & 8.13 & 2.41 & 0.10 & 0.08 \\
\hline Intercept & 2186.36 & 1 & 2186.36 & 648.88 & 0.00 & 0.92 \\
\hline PreTest & 13.24 & 1 & 13.24 & 3.93 & 0.05 & 0.07 \\
\hline Gender & 3.88 & 1 & 3.88 & 1.15 & 0.29 & 0.02 \\
\hline Error & 178.58 & 53 & 3.37 & & & \\
\hline Total & 50775.00 & 56 & & & & \\
\hline Corrected Total & 194.84 & 55 & & & & \\
\hline
\end{tabular}

$F(1,53)=1.15 ; p=0.29>0.05$, as seen in Table 7. As a result, the null hypothesis is not ruled out. This indicates that there is no statistically significant difference in the mean accomplishment scores of male and female students in Basic science who are exposed to the simulation technique. According to data analysis, there is no statistically significant difference in the average success of female and male students in Basic science when simulation approach is used. This is based on the analysis's findings. With a partial Eta square of 0.02 for gender, only $2 \%$ of Basic Science students' performance results in simulation class can be accounted for by their gender. 
Table 8. ANCOVA of mean retention scores of male and female students in basic science who are exposed to simulation strategy

\begin{tabular}{lcccccc}
\hline \multicolumn{1}{c}{ Source } & $\begin{array}{c}\text { Type III Sum } \\
\text { of Squares }\end{array}$ & df & $\begin{array}{c}\text { Mean } \\
\text { Square }\end{array}$ & F & Sig. & $\begin{array}{c}\text { Partial Eta } \\
\text { Squared }\end{array}$ \\
\hline Corrected Model & $103.64^{a}$ & 2 & 51.82 & 13.41 & 0.00 & 0.34 \\
\hline Intercept & 2143.70 & 1 & 2143.70 & 554.61 & 0.00 & 0.91 \\
\hline PreTest & .50 & 1 & 0.50 & 0.13 & 0.72 & 0.02 \\
\hline Gender & 101.79 & 1 & 101.79 & 26.33 & 0.00 & 0.33 \\
\hline Error & 204.86 & 53 & 3.87 & & & \\
\hline Total & 41892.00 & 56 & & & & \\
\hline Corrected Total & 308.50 & 55 & & & & \\
\hline
\end{tabular}

$F(1,53)=26.33 ; p=0.000 .05$, as seen in Table 8. In this case, the null hypothesis is rejected. This indicates that there is a substantial difference in the mean retention scores of male and female students subjected to simulation technique in basic science. As a result, it is determined that there is a substantial difference in the mean retention scores of male and female students in basic science when they are subjected to simulation approach. The partial Eta square for gender was 0.33, indicating that 33\% of the retention scores of Basic Science students may be accounted for by their gender in simulation class.

\section{DISCUSSION}

A study found that there is a statistically significant difference between the achievement of students in Basic science who were applied to simulation approach vs those who were taught using demonstration technique in one of the studies. This suggests that simulation approach, rather than demonstration strategy, may be a more effective method of teaching Basic Science. Similarly to the findings of Bello et al. (2016), the present study demonstrates that the use of simulation strategies improves students' academic performance in Basic Science at the elementary level of education at Mafoni Day Secondary School Maiduguri, Nigeria. The findings are also consistent with those of Ayuba (2017), who discovered that there is a statistically significant difference in performance between students who get computer-based instruction (CBI) and those who receive lecture-based teaching. The findings are also in agreement with those of Nwodo (2018), who found that the simulation approach is better in terms of student accomplishment when compared to the lecture technique in terms of student achievement.

The findings are also consistent with those of Awodun and Oyeniyi (2018), who found that there was a statistically significant difference in academic accomplishment in Basic Science between the experimental and control groups, with the experimental group outperforming the control group. The results are also consistent with those of Agu and Samuel (2018), who discovered that there were statistically significant changes in the accomplishment of students who were taught utilizing a simulation instructional program, as opposed to the more traditional manner. According to the findings of Agu and Samuel (2018), there were statistically significant variations in the accomplishment of students who were exposed to a simulation instructional package compared to students who were exposed to guided exploration approaches. In a similar vein, the findings of Isah (2021) that there is a statistically significant difference in mean accomplishment scales between 
students taught Biology using Facebook and simulation instructional tactics and students taught Biology using lecture methods are also supported by this research.

The simulation strategy has been effectively utilized for the purpose of instruction in Basic Science class to help enhance students' achievement, as evident in the significant difference found in the present research. This is because the use of simulation addressed directly the learning objective and the features or attributes that are conceded relevant, indisputable, and common to the objectives. The use of simulation strategy better prepares students to understand basic science well and professionals involved in education at all levels who are still struggling to make sure that the acquisition, introduction of active methodologies in the classroom might have turned into understanding that formal instruction becomes a precursor to life-long learning. The use of simulation strategy as an innovative teaching strategy that is learner-centered allow students to project themselves into new classroom roles that improve their achievement, as evident in the significant difference found in the present research.

Results indicated that there is a statistically significant difference between scores of students in upper basic II Basic science who were applied to simulation strategy against those who were exposed to demonstration strategy over the study period. This suggests that the use of the simulation technique resulted in greater retention of information by students than the use of the demonstration strategy. The findings are consistent with those of Ayuba (2017), who discovered a statistically significant difference in retention in favor of students who received computer-based instruction (CBI) as opposed to their counterparts who received lecture-based teaching. It is also consistent with the findings of Agu and Samuel (2018), who discovered statistically significant differences in retention between students taught using a simulation instructional package and students taught using the traditional technique. It was discovered, in accordance with the findings of Agu and Samuel (2018), that there were statistically significant variations in the retention of students exposed to the simulation instructional package when compared to guided exploration approaches. Finding agrees with that of Nwodo (2018) that simulation strategy is more superior in terms of students' retention compared to the lecture method.

The adoption of simulation strategy in the present study engenders the eventual effect of alternative situations and cause of action. This is because the use of simulation strategy provides a simplified instructional process where students solve problems, learn procedures, and come to understand the characteristic of phenomena and how to control them or learn what action to take in different situations. This may be responsible for the significant difference found in the present paper. The use of simulation strategy also helps the student build a useful mental model of the learning materials and prove an opportunity to transcript it safely and efficiently. The learners who form the mental model of learning materials independently using a simulation-based tool gained better retentive ability than learners who listened to the same concepts presented by the demonstration strategy. This may be practically responsible for the significant difference in retention scores found in the present study.

There is no statistically significant difference between female and male students in Basic science who are applied to simulation strategy, according to the findings of the study that looked at the usage of simulation strategy and gender. This suggests that the adoption of simulation strategies is gender-neutral in terms of improving students' accomplishment 
levels. The findings are consistent with those of Ayuba (2017), who discovered that there is no statistically significant difference in performance between men and girls exposed to CBI. The findings are also consistent with those of Nwodo (2018), who found that male and female students who were taught using the simulation approach got almost identical results.

Gender stereotyping permeated the Basic Science class when simulation strategy was used to teach Basic II students. The present study found no significant difference in the mean achievement scores of male and female students in Basic science simulation classes. This is because the effective use of simulation strategy is capable of bridging the gender gap, as findings have shown that the instructional strategy is gender-friendly. The simulation strategy was used through role-plays, games, and computer programs that make students active participants in the classroom. The active participation of both male and female students is responsible for the bridging of the gender gap in students' achievement in simulation class.

The study on the use of simulation strategy and sexual identity found that there is a big difference in the mean retention scores of male and female students who are applied to simulation strategy. This implies that the use of simulation strategy is not gendered friendly in enhancing students' retentive ability. The finding agrees with that of Awodun (2017) that the post-test mean scores of the experimental group were significantly higher than the posttest mean scores of the control group. However, the findings disagree with that of Nwodo (2018) that male and female students taught with simulation method retained almost equal scores.

Simulated teaching of Basic Science made students less likely to remember what they learned when gender stereotypes were used. Male and female students' retention rates were found to be very different, and this was a big difference. Use of a simulation strategy, on the other hand, is supposed to help close this kind of gap. The use of a simulation strategy should make it easier for students to remember information from memory and apply it in a different way than they did when they first learned it. This made Basic Science class more effective for students regardless of their gender. The student achievement does not differ by gender in simulation strategy class, but their retention differs because simulation strategy as a teaching process functions better among male students as observed over a long period of time.

\section{CONCLUSION}

Based on the results obtained in this research, it was concluded that using simulation strategy to improve students' achievement and retention in Basic Science demonstration strategy. The use of simulation strategy is gender-friendly in terms of male and female students' achievement in Basic Science and gender-sensitive in terms of male and female students' retention in Basic science. Based on the findings of present research, the following suggestions are made:

1. Basic Science teachers should employ a simulation strategy to teach and learn various topics in Basic science to improve students' achievement in Basic Science.

2. Through Universal Basic Education Commission, the State Government should workshops, conferences, and symposia for Basic Science teachers on the use of 
simulation strategy in schools to pave the way for its adoption, considering its potential to improve students' retention in Basic Science.

3. Curriculum and planners should adopt the simulation strategy and create more learning activities that engender equal instructive opportunities for both male and female students to avoid gender stereotyping in Basic Science

\section{REFERENCES}

Achor, E. E. \& Eriba, J. O. (2010). School type and sex of teacher as factors in classroom interaction patterns in integrated science. Journal of Research Review in Curriculum and Teaching, 5(1), 406-41.

Adeyemi, B. A \& Ajibade, Y. A. (2011).The comparative effects of simulation games and brainstorming instrumental strategies on Junior Secondary School Students achievement in Social studies in Nigeria. African Research Review, 5(20), 64-809 https:// doi.org/10.4314/afrrev.v5i3.67342

Agogo, P. O. \& Naakaa, D. A. (2014). Effect of 5Es constructivist instructional strategy on students' interest in senior secondary genetics in Gwer Local Government Area of Benue State, Nigeria. Global Journal of Environmental Science and Technology, 1(2),1519.

Agu, P. A. \& Samuel, T. R. (2018). Effect of simulation instructional package on basic science and technology, students achievement and retention in federal capital territory, Abuja, Nigeria. International Journal of Innovation Education Research, 6(3), 1-7. https://doi.org/10.20448/journal.509.2019.63.129.134

Ajayi, V. O. (2019). Effect of predict-explain-observer explain and veeheuristic strategies on students achievement, metacognitive awareness and self-efficacy belief in Organic Chemistry in Ekiti State, Nigeria. Unpublished PhD thesis, Benue State University, Makurdi. https://doi.org/10.2139/ssrn.3587073

Ameh, I. E. T., Daniel, B. P. \& Akus, Y. (2007). Researchand methods in social science. Ankpa: Rowis Press

Asogwa, U. D., Muhammed, A., Asogwa, E. N., \& Ofoegbu, T. O. (2016). Effect of interactive computer simulation package on senior secondary school students' achievement and retention in genetics concepts. Asian Journal of Information Technology. 15(14), 23132321

Awodun, A. O. \& Oyeniyi, A. D. (2018). Effect of instruction simulation on students' performance in Basic science in junior secondary school in Ekiti State. International Journal of Research and Analytical Reviews (IJRAR), 5(2), 23-27

Awodun, A. 0. (2017). Concept mapping teaching strategy on students' academic performance and retention in secondary school physics students in Ekiti state, Nigeria. International Journal for Research in Educational Studies (JIERS), 3(6)1-9.

Ayodele, M. O. (2016).Attitude, self-concept and achievement of Junior Secondary School Students in Basic Science in Ekiti State, Nigeria. Journal of Educational and Social Research, 6(1)167-172. https://doi.org/10.5901/jesr.2016.v6n1p167

Ayuba, I. (2017). Effects of based instructions on retention and performance in algebraic word problems amongst junior secondary school students in Kaduna state-Nigeria. M. Ed dissertation, Ahmadu Bello University, Zaria.

Babajide, S. K. (2010). Blue print for the management of the UBE at the secondary school 
level. Paper Presented at the National Workshop on Effective School Management and challenge of Conducting School Examination in Nigeria, Organized by all Nigerian conference of Secondary School principals (ANCOPSS) March.

BECE. (2020). Analysis of students performance basic education certificate examination 2010-2019, Ankpa Education Zone Statistics Office, Ankpa.

Bello, S., Ibi, M. B., \& Bukar, T. B. (2016). Effect of simulation techniques and lecture methods on students' academic performance in Mafoni day secondary school, Maiduguri, Borno State, Nigeria. Journal of Education and Practice, 7(23), 113-117.

Bhure, M., Welu, F., See, S., \& Ota, M. K. (2021). The effort to enhance pupils cognitive learning achievement using contextual teaching and learning approach. Journal of Research in Instructional, 1(1), 13-22. https://doi.org/10.30862/jri.v1i1.3

Blair, K, Schwartz, D. L., Biswas, G. \& Leelawong, K. (2007). Pedagogical agent for learning and teaching: Teachable agents. Educational Technology, 47(1), 6-61.

Bunkola, B. A. J. \& Idowu, O. D. (2012).Effectiveness of comparative learning strategies on Nigeria Junior Secondary Students academic achievement in Basic Science. British Journal of Education, Society and Behavioural Sciences, 2(3), 207-325. https://doi.org/10.9734/BJESBS/2012/1628

Cayirci, E. (2013). Modeling and simulation as a cloud service: A survey, in Simulation Conference. Winter Journal of Leadership, 2(3), 389-400. https://doi.org/10.1109/WSC.2013.6721436

Ellah, B. \& Achor, E. E. (2015). Cognitive styles and Attitude to Science of Senior Secondary School Science Students of High Cognitive Ability Level. Journal of the International Centre for Science, Humanity and Education Research, 1(3), 10-26.

Ellah, B. \& Achor, E. E. (2017). Achievement in Basic Science and technology as correlates of student performance in science in senior Secondary Schools in Nigerian. International Centre for Science Humanities and Educational Research Journal, 3(2), 7383.

Emaikwu, S. O. (2019). Fundamentals of research methods and statistics, Makurdi: Selfers Academic Press Ltd.

Hursen, A. (2015). The effect of simulation methods in teaching physics on students' academic success. World Journal of Educational Technology, 7(1), 87- 78.

Igboegwu, E. N. (2012). Effect of guided discovery and demonstration teaching methods on achievement of chemistry students of different level of scientific literacy. Journal of Research in Curriculum and Teaching, 6(1), 445-458.

Isah, A. A. M. (2019). Effect of facebook and simulation on senior secondary students' attitude and achievement in Biology in FCT-Abuja. Unpublished PhD Thesis, Benue State University, Makurdi, Nigeria

Nwafor, C. E. (2015). Comparative study of science students in public and private secondary schools in Ebonyi state Nigeria. Academic Discourse: An International Journal of Psychological Studies. 3(1).

Nwodo, P. N. (2018). The effect of simulation method on students' achievement and retention in some concepts in government at senior secondary school in Nsukka education zone, M.Sc dissertation submitted to Faculty of Education University of Nigeria, Nsukka.

Obiekwe, C. K. (2008). Effect of constructional instructional approach on students' 
achievement and interest in basic ecological concept in biology. Unpublished M. Ed Thesis, University of Nigeria, Nsukka.

Oludipe, D. I. (2012). Gender difference in Nigerian junior secondary students' academic achievement in basic science. Journal of Educational and Social Research, 2(1), 93 - 99

Pember, S. T. \& Achor, E. E. (2017). Computer simulated experiments and Senior Secondary Students achievement in practical Physics in Nigeria. Journal of the International Centre for Science, Humanities and Education Research, 3(2), 1-17

Ruto, R., Mema, A., Nduru, M. P., \& Ota, M. K. (2021). Contextual teaching and learning approach in social science: its role to encourage pupils' cognitive learning achievement. Journal of Research in Instructional, 1(1), 43-52. https://doi.org/10.30862/jri.v1i1.11

Seay, D. T. \& Jouhingen, W. V. (2013). What do we know about computer simulations? Retrieved 7th August 2018 from http://kaliedoscope.gw.utwentee.ml/SIG-ILI

Sidi, D. (2009). The effect of constructivist teaching strategy on students' attitude and achievement in biology. Unpublished M. Ed Thesis, University of Jos. Plateau State.

Sokolowski, J. A. \& Banks, C. M. (2009). Principles of modeling and simulation. New Jersey: Hoboken. https://doi.org/10.1002/9780470403563

Wood, W. B. \& Gentile, J. M. (2003). Teaching in research content in science. 302: 15-10. https://doi.org/10.1126/science.1091803 